China, had to rely entirely on wireless communications with foreign countries. This is sufficient proof of the precarious value of the cables in case of emergency, no matter how big a navy patrols the Pacific.

Chinese radio communications likewise have suffered heavily. The central telephonic and telegraphic station of Shanghai at Chenju was completely demolished by aerial bombing on September 3 (as had been done before, during the Shanghai War in 1932).

What remains of the Chinese communications, the Japanese try to "drown" by their interference sta- tion which was erected some time ago in South Manchuria with the special purpose of blotting out the Nanking programs. In addition, the Japanese swamp the whole world with their broadcasting publicity from Tokyo, Dairen, and the powerful station in Changchun, which was erected in 1934 for propaganda purposes in Manchuria.

If China's resistance should break down, there is no doubt that her whole communication system would be crushed; simultaneously, the interests of western powers would be eliminated.

\title{
FATE OF AN INTERNATIONAL FILM INSTITUTE
}

\section{By HILLA WEHBERG}

Miss Wehberg is a graduate of the University of Chicago and has lived in Geneva, Switzerland, for a number of years. She is now assisting in a course on the educational sociology of the motion picture at New York University.

When the Italian delegation left Geneva in May 1936, it carried with it a death blow for the International Educational Cinematographic Institute of Rome. This Institute is one of the many special institures put at the disposal of the League by certain governments.
The Swiss are very much concerned about the future of the Institute and they have reason to be. In 1923 the International Student Congress in Oxford asked the Swiss Student Association to organize the international educational film field. A committee headed by Dr. Franz Heinemann set to work in Zürich. It undertook to build up an International Film Library, and served as a clearing house for international educational film information.

Herriot, Stresemann, and Mussolini were sympathetic to the enter- 
prise and the Zürich group hoped to become an official organ of the League.

Then in 1927 the Council of the League named Rome instead of Zürich as the official seat of the International Educational Cinematographic Institute. The material which had been gathered in Zürich was sent to Rome. Those connected with the work in Zürich were shocked and disappointed.

The Rome Institute opened in November 1928. It was heavily financed by the Italian Government, received donations from individuals and institutions. Its aim was to encourage production, circulation, and exchange of educational films. The administration consisted of a Governing Body, a Permanent Executive Committee, an Advisory and Technical Committee, and a Director.

\section{Work of the Institute}

The Institute organized a Convention in 1933 which served "to make known educational films and to facilitate the transport and showing of such films in educational establishments and in cinema halls." 1

In 1934 the Institute organized an International Congress of teaching and educational cinematography and two Conferences for the standardization of dimensions of sound films.
Besides several monographs on such subjects as The Cinema and Health, The Cinema and the Teaching of Languages, The Cinema and Scientific Organizations of Labor, etc., the Institute has published: (I) An International Review of Educational Cinematography (July 1929December 1934), renamed Intercine (January-December 1935); and (2) A Cinematographic Encyclopedia, completed in 1937 .

The magazine appeared in five languages. It discussed the technical, social, legal, educational, and artistic aspects of the film medium.

In 1929 the magazine carried articles on such subjects as the documentary film, copyrights in cinematographic productions, and religion in the cinema.

In $193^{\circ}$ many of the articles were written by Russians and a film on motherhood was discussed in a section devoted to social propaganda.

The I93I volume of the review contains a section on "Sociology and Cinema."

Most complete and interesting is the one volume of Intercine: Max Factor writes in detail about screen make-up; Alistair Cooke on "Trends in British Films"; Paul Rotha on "The Future of Documentary." Other subjects of interest to screen technicians as well as film

1 League of Nations. Handbook of International Organizations. Geneva, 1938. 
industry men are discussed, and there are plenty of pictures. ${ }^{2}$

The files and research material of the Institute are said to contain abundant information on all aspects of the film medium, arranged in such a way that students of all fields and all lands can make use of them.

In December 1937, apparently because of the political situation, the President of the Institute reported to the Council and Members of the League that the director and ali officials and employees (except for three employed on an international basis) had handed in their resignation as of December 3I, 1937.

The President added that he had asked the Director, Dr. Luciano de Feo, "to remain temporarily in charge for the purpose of liquidating the whole staff, settling all outstanding business in the best possible way, and immediately thereafter, closing the Institute down."

If there is to be a new international cinema center, where will it be established? To what extent would the new center be able to profit from the Italian work and experience? If the Zürich group gave its material to Rome, is it likely that the Rome group will give its material to a new institute? Will Zürich be the new headquarters? Undoubtedly, an institution for the production, circulation, and exchange of educational films might profit from being placed on neutral political soil. ${ }^{3}$

2 Files of Intercine are in the Woodrow Wilson Memorial Library and the New York Public Library.

${ }^{3}$ For further details see: "Schicksale des Internationalen Lehrfilm-Instituts in Rom," Luzerner Netueste Nachrichten, December 27, 1937; and "Das Internationale Lehrfilminstitut gehört in die Schweiz," Neue Züricher Zeitung, December 29, 1937.

\section{INSTITUTE FOR EDUCATION BY RADIO}

\section{By NORMAN WOELFEL}

Mr. Woelfel is Research Associate in the Social Studies for the Evaluation of School Broadcasts, a study sponsored by the Federal Radio Education Committee of the Federal Communications Commission at the Ohio State University.

Professor Boyd H. Bode of Ohio State University offered a challenging analysis of general educational needs at the opening session of the Ninth Institute for Education by Radio held at Columbus, Ohio, on May 2, 3, 4, 1938. Professor Bode made clear to his panel and to the audience of two hundred delegates the American cultural crisis of the present day. 